\title{
Reanalysing the 2007-19 glaciological mass-balance series of Mera Glacier, Nepal, Central Himalaya, using geodetic mass balance
}

\section{Article}

Cite this article: Wagnon P et al. (2021). Reanalysing the 2007-19 glaciological mass-balance series of Mera Glacier, Nepal, Central Himalaya, using geodetic mass balance. Journal of Glaciology 67(261), 117-125. https://doi.org/10.1017/jog.2020.88

Received: 5 May 2020

Revised: 16 September 2020

Accepted: 17 September 2020

First published online: 4 November 2020

Key words:

Glacier mass balance; glacier monitoring; mountain glaciers

Author for correspondence:

Patrick Wagnon,

E-mail: Patrick.wagnon@univ-grenoble-alpes.fr

\author{
Patrick Wagnon ${ }^{1,2}$, Fanny Brun ${ }^{1,3}$ (D), Arbindra Khadka ${ }^{2,4}$, Etienne Berthier ${ }^{5}$ (D), \\ Dibas Shrestha ${ }^{4}$, Christian Vincent ${ }^{1}$, Yves Arnaud ${ }^{1}$, Delphine Six ${ }^{1}$, \\ Amaury Dehecq ${ }^{6,7}$ (D), Martin Ménégoz ${ }^{1}$ and Vincent Jomellis,9
}

${ }^{1}$ Univ. Grenoble Alpes, CNRS, IRD, IGE, F-38000 Grenoble, France; ${ }^{2}$ ICIMOD, GPO Box 3226, Kathmandu, Nepal; ${ }^{3}$ Department of Physical Geography, Utrecht University, Utrecht, The Netherlands; ${ }^{4}$ Central Department of Hydrology and Meteorology, Tribhuvan University, Kathmandu, Nepal; ${ }^{5}$ LEGOS, Université de Toulouse, CNES, CNRS, IRD, UPS, 31400 Toulouse, France; ${ }^{6}$ Laboratory of Hydraulics, Hydrology and Glaciology (VAW), ETH Zürich, Zürich, Switzerland; ${ }^{7}$ Swiss Federal Institute for Forest, Snow, and Landscape Research (WSL), Birmensdorf ZH, Switzerland; ${ }^{8}$ LGP UMR 8591 CNRS Paris 1 Panthéon-Sorbonne University CNRS, 92195 Meudon, France and ${ }^{9}$ CEREGE. UMR 7330 Aix-Marseille University- CNRS-IRD-Coll. France-INRAE, 13545 Aix-en-Provence, France

\begin{abstract}
The 2007-19 glaciological mass-balance series of Mera Glacier in the Everest Region, East Nepal, is reanalysed using the geodetic mass balance assessed by differencing two DEMs obtained from Pléiades stereo-images acquired in November 2012 and in October 2018. The glaciological glacier-wide annual mass balance of Mera Glacier has to be systematically decreased by $0.11 \mathrm{~m}$ w.e. $\mathrm{a}^{-1}$ to match the geodetic mass balance. We attribute part of the positive bias of the glaciological mass balance to an over-estimation of the accumulation above $5520 \mathrm{~m}$ a.s.l., likely due to a measurement network unable to capture its spatial variability. Over the period 2007-19, Mera Glacier has lost mass at a rate of $-0.41 \pm 0.20 \mathrm{~m}$ w.e. $\mathrm{a}^{-1}$, in general agreement with regional averages for the central Himalaya. We observe a succession of negative mass-balance years since 2013.
\end{abstract}

\section{Introduction}

Many international institutions such as the European Space Agency or the World Meteorological Organization, recognize glacier mass balance as one of the essential climate variables (Dolman and others, 2016) required for climate system monitoring because it has a direct and undelayed response to atmospheric climate change (e.g., Oerlemans, 2001). Long-term in situ glacier monitoring is thus crucial in the present context of global warming. Of the 41 glaciers worldwide listed as 'reference glaciers' by the World Glacier Monitoring Service (WGMS), none are located in the Hindu Kush-Karakoram-Himalaya (HKH) region (Bolch and others, 2019; Zemp and others, 2019). The HKH, however, hosts the largest glacierized area outside the polar regions (Pfeffer and others, 2014; Bolch and others, 2019), with large and rapidly growing populations living downstream and partly relying on glacier meltwater for their hydro-economy (e.g., Immerzeel and others, 2019; Pritchard, 2019). In $\mathrm{HKH}$, mass-balance series are short (often $<1$ decade), often discontinuous, and lack validation and calibration using decadal geodetic surveys (Azam and others, 2018).

There are $\sim 15$ glaciers presently surveyed in HKH using the classical glaciological method (Azam and others, 2018). Only two series have been validated using geodetic surveys so far: Chhota Shigri Glacier in Northern India in the western Himalaya initiated in 2002, the longest mass-balance record in HKH (Azam and others, 2016) and West Changri Nup Glacier in eastern Nepal, in the central Himalaya, initiated in 2010 (Sherpa and others, 2017). In Nepal, the longest series initiated in 2007 comes from Mera Glacier but its calibration or validation using a geodetic survey is needed, as recommended by Zemp and others (2013).

The objectives of this contribution are to update the on-going mass-balance series of Mera Glacier, to compare it with the geodetic mass balance assessed between 2012 and 2018 using DEM differencing, to identify potential biases and to track the sources of such biases using a combination of in situ and remotely sensed measurements.

\section{Study site}

Mera Glacier $\left(27.7^{\circ} \mathrm{N}, 86.9^{\circ} \mathrm{E}, 5.06 \mathrm{~km}^{2}\right.$ in 2012$)$ is a debris-free summer-accumulation glacier located in the upper Dudh Koshi basin, in the Everest region (Central Himalaya) (Fig. 1). From the summit at $6390 \mathrm{~m}$ a.s.l., the glacier flows north and divides into two main branches at $5780 \mathrm{~m}$ a.s.l., the Mera branch oriented north and then west down to $4910 \mathrm{~m}$ a.s.l. and the Naulek branch oriented north-east until its lowest elevation at $5220 \mathrm{~m}$ a.s.l. Details regarding the characteristics of Mera Glacier as well as the climate conditions in which it is located can be found in Wagnon and others (2013). 


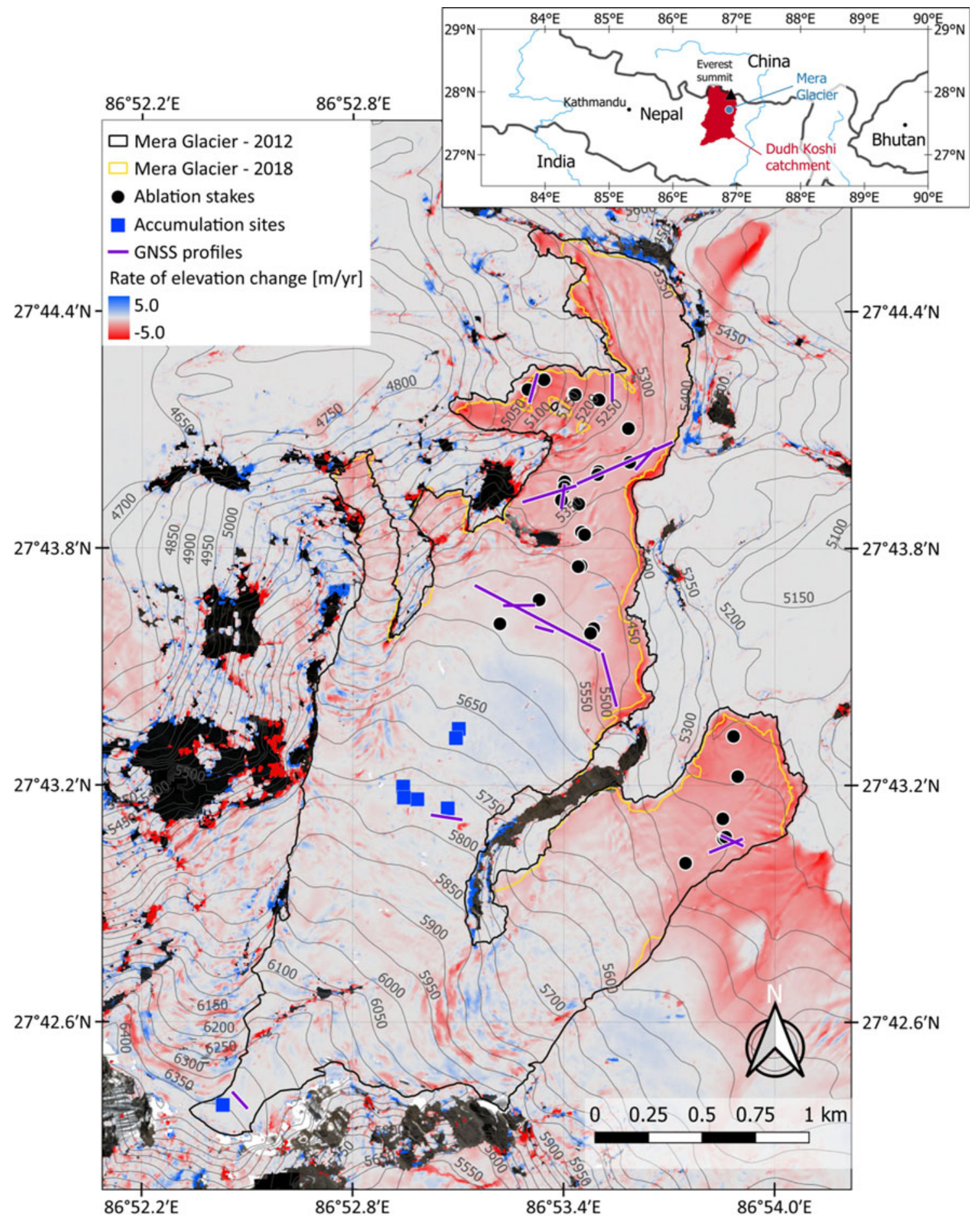

Fig. 1. Map of 2012-18 elevation change (in $\mathrm{m} \mathrm{a}^{-1}$ ) of Mera Glacier showing the network of ablation stakes (black dots), the accumulation sites (blue squares), the transverse and longitudinal profiles surveyed by differential global navigation satellite system (GNSS) to measure elevation changes (purple lines) and the glacier outlines in 2012 (black line - total glacier area of $5.06 \mathrm{~km}^{2}$ ) and 2018 (yellow line - total glacier area of $4.84 \mathrm{~km}^{2}$ ). Black zones are steep areas with no data. Elevation lines are extracted from the 2012 Pléiades DEM. The inset map gives the location of Mera Glacier and the Dudh Koshi catchment in Nepal.

\section{Data and methodology}

\subsection{Glacier-wide mass balance from the glaciological profile method}

The annual glacier-wide mass balance $B_{a}$ is calculated according to:

$$
\left.B_{a}=\frac{1}{S} \sum_{z} b_{z} s_{z} \text { (in m w.e. } \mathrm{a}^{-1}\right)
$$

where $b_{z}$ is the point surface mass balance ( $\mathrm{m}$ w.e. $\mathrm{a}^{-1}$ of a given elevation band, $z$, of area $s_{z}\left(\mathrm{~m}^{2}\right)$ and $S$ is the total glacier area $\left(\mathrm{m}^{2}\right)$. Point mass-balance measurements have been performed every year in November since 2007 (early December in 2014 and 2015). They are obtained from temporal emergence differences of bamboo stakes and/or manual drillings in the accumulation area using an artificially coloured snow layer to undoubtedly localize the previous year horizon (Fig. 1). Ice density is taken as $900 \mathrm{~kg} \mathrm{~m}^{-3}$ and snow densities are measured in the field, ranging from $370 \pm 30 \mathrm{~kg} \mathrm{~m}^{-3}$ in the ablation area to $400 \pm 40 \mathrm{~kg} \mathrm{~m}^{-3}$ in the uppermost accumulation area. More details regarding the methodology are provided in Wagnon and others (2013) and Sherpa and others (2017). Contrary to those two studies in which glacier hypsometry (and consequently total area) was 
considered unchanged, here it is assumed to vary linearly with time over the measurement period (2007-19). The rate of area changes for each altitude band is derived from the glacier hypsometries in 2012 and 2018, extracted from Pléiades DEMs where glacier outlines are manually delineated (see Section 3.2. and the 2012 and 2018 glacier outlines in Fig. 1). Mass balance is obtained for every $10 \mathrm{~m}$ altitudinal range using linear fits to all available in situ point mass-balance measurements versus elevation, considering separately the accumulation area and both branches of the ablation area, i.e. Mera and Naulek branches (Fig. 1). The number of point mass-balance measurements varies from seven in 2012/13 to a maximum of 33 in 2017/18, depending on how many stakes are broken or buried by snow (Table 1). Every $10 \mathrm{~m}$ altitudinal range area is then multiplied by its corresponding mass balance, summed over the entire glacier and finally divided by the total glacier area $S$ to get the glacier-wide mass balance (Eqn (1)). Averaging the errors related to the measurements themselves and the distribution of sampling sites, we obtain a mean overall accuracy of $\pm 0.28 \mathrm{~m}$ w.e. $\mathrm{a}^{-1}$ for $B_{a}$ (Wagnon and others, 2013).

The supplementary text (section S3) presents an alternative method to estimate the annual glacier-wide mass balance from point measurements using the nonlinear model of Vincent and others (2018). This model is applied not only for comparison purposes but above all to carry out a rigorous evaluation of uncertainties (see Section 4.3. and supplementary section S3.2).

\subsection{Glacier-wide mass balance from the geodetic method}

\subsubsection{2-18 mass balance using DEM differencing}

Two $4 \mathrm{~m}$ DEMs are generated using the Ames Stereo Pipelines (Berthier and others, 2014; Shean and others, 2016) from Pléiades stereo pairs acquired on 25 November 2012 and 28 October 2018. The October 2018 DEM is co-registered to 478 global navigation satellite system (GNSS) points collected on-glacier between 20 and 25 November 2018 using the Nuth and Kääb (2011) methods (Fig. S1 of the supplementary information). The mean elevation difference between the GNSS points and DEM is $0.03 \mathrm{~m}$ (the median is set to $0 \mathrm{~m}$ in the co-registration procedure) and the standard deviation of the differences is $0.48 \mathrm{~m}$. The November 2012 DEM is then co-registered to the October 2018 DEM (Nuth and Kääb, 2011) using nearly 4 megapixels over the stable terrain and DEMs are differentiated. The map of elevation change is almost gap-free on Mera Glacier $(<1 \%$ of voids). We calculate the mean elevation change using the local mean hypsometric method (McNabb and others, 2019) on bins of $10 \mathrm{~m}$ after filtering out pixels whose value differ by more than five normalized median absolute deviation (NMAD) from the mean (Höhle and Höhle, 2009), which represent $4 \%$ of the pixels. The total volume change $(\Delta V)$ is defined as $\Delta V=d h \times S_{2012}$ where $d h$ is the glacier mean elevation change $(\mathrm{m})$ and $S_{2012}\left(\mathrm{~m}^{2}\right)$ is the glacier area in 2012.

The geodetic mass balance $\left(B_{g}\right)$ is then calculated as:

$$
B_{g}=f_{\Delta V} \frac{\Delta V}{\left(S_{2012}+S_{2018}\right) / 2} \times 10^{-3} \text { (in m w.e.) }
$$

where $f_{\Delta V}=850 \mathrm{~kg} \mathrm{~m}^{-3}$ is the volume to mass conversion factor i.e. the assumed density of the lost volume averaged over the entire glacier (Huss, 2013) and $S_{2018}$ the glacier area in 2018. The factor $10^{-3}$ is needed to convert the geodetic mass balance from $\mathrm{kg} \mathrm{m}^{-2}$ (i.e. $\mathrm{mm}$ w.e.) to $\mathrm{m}$ w.e.
The uncertainty on the volume change $\left(\sigma_{\Delta V}\right)$, is calculated as a quadratic sum:

$$
\sigma_{\Delta V}=\sqrt{\left(S_{2012} \times \sigma_{d h}^{\prime}\right)^{2}+\left(d^{\prime} h \times \sigma_{S_{2012}}\right)^{2}}\left(\text { in }^{3}\right)
$$

where the uncertainty on the mean elevation change $(\sigma$, in $\mathrm{m})$ is assessed using the so-called patch method, which consists in sampling patches of the stable terrain that have various areas, in order to constrain empirically the decay of the error with the averaging area (Miles and others, 2018 and section S2 of the supplementary information). The uncertainty on the area $\left(\sigma_{S_{2012}}\right.$ in $\left.\mathrm{m}^{2}\right)$ is calculated as the product of the outline perimeter and twice the ground sampling distance of the Pléiades panchromatic images $(1.5 \mathrm{~m})$. The uncertainty on the geodetic mass balance $\sigma_{B_{g}}$ is calculated as:

$$
\sigma_{B_{g}}=\frac{10^{-3}}{\left(S_{2012}+S_{2018}\right) / 2} \sqrt{\left(f_{\Delta V} \times \sigma_{\Delta V}\right)^{2}+\left(\Delta V \times \sigma_{f_{\Delta V}}\right)^{2}} \text { (in m w.e.) }
$$

where $\sigma_{f_{\Delta V}}=60 \mathrm{~kg} \mathrm{~m}^{-3}$ is the uncertainty on the volume to mass conversion factor (Huss, 2013). The factor $10^{-3}$ is needed to obtain the uncertainty of the geodetic mass balance in $\mathrm{m}$ w.e. We assume no uncertainty on the area in this calculation, as the uncertainty on the area is taken into account in the uncertainty on the volume change.

\subsubsection{Validation of satellite-derived elevation change using differential GNSS data}

Fourteen transverse and longitudinal profiles located at different elevations over adequate areas of the glacier (preferentially smooth and flat areas; Fig. 1) are regularly surveyed using dual frequency differential GNSS Topcon units in stop-and-go mode, with an occupation time of five to $10 \mathrm{~s}$ and a minimum of seven visible satellites (GPS and GLONAS). From these repeated surveys, we measure the glacier thickness changes exactly along these profiles with an accuracy of $\pm 0.10 \mathrm{~m}$ (Vincent and others, 2016). Each profile is split into $25 \mathrm{~m}$ long individual sections over which the differential GNSS and DEM-derived elevation changes are compared. Such differential GNSS surveys are time-consuming in the field and sometimes prone to some differential GNSS failure, and therefore they are not conducted every year for each profile. Figure 2 shows the comparison between annual rates of elevation changes of the profiles surveyed in the field using differential GNSS over different periods and the corresponding annual elevation change rate assessed by DEM differencing between 25 November 2012 and 28 October 2018. For each $25 \mathrm{~m}$ long section, we average the Pléiades DEM difference on a $20 \mathrm{~m}$ diameter circle centred on the middle of the section. Averaging over a $20 \mathrm{~m}$ circle instead of taking pixelbased values reduce potential biases originating from (i) the co-registration of the 2018 DEM on the GNSS points, and (ii) the nonperfectly smooth surface at and around the profiles. The Pléiades stereo-images were acquired exactly at the same time as the field measurements in 2012 (Berthier and others, 2014), but 4 weeks earlier in 2018. No snowfall was recorded during these 4 weeks and ablation was assumed to be negligible during this period of the year (November 2018). Thus, no correction is applied to compare elevation changes from differential GNSS field measurements and DEM differencing. The remarkable agreement between field and satellite data (Fig. 2 - green diamonds) gives confidence in the relative accuracy of the DEMs and in turn in the geodetic mass balance of Mera Glacier. The limited bias $(-0.24 \mathrm{~m})$ and the standard deviation $(0.52 \mathrm{~m})$ when the same time period is considered (Fig. 2) are in line with previous assessments of Pléiades DEMs 
Fig. 2. Comparison between annual rates of elevation changes (in $\mathrm{ma}^{-1}$ ) of $25 \mathrm{~m}$ long sections (dots and diamonds) obtained from differential GNSS field measurements along transverse or longitudinal profiles over different periods (from November 2009, 2010, 2012, 2014 or December 2015 to November 2018) and derived by Pléiades DEMs differencing between 25 November 2012 and 28 October 2018. The 1:1 line is shown as a dashed line.

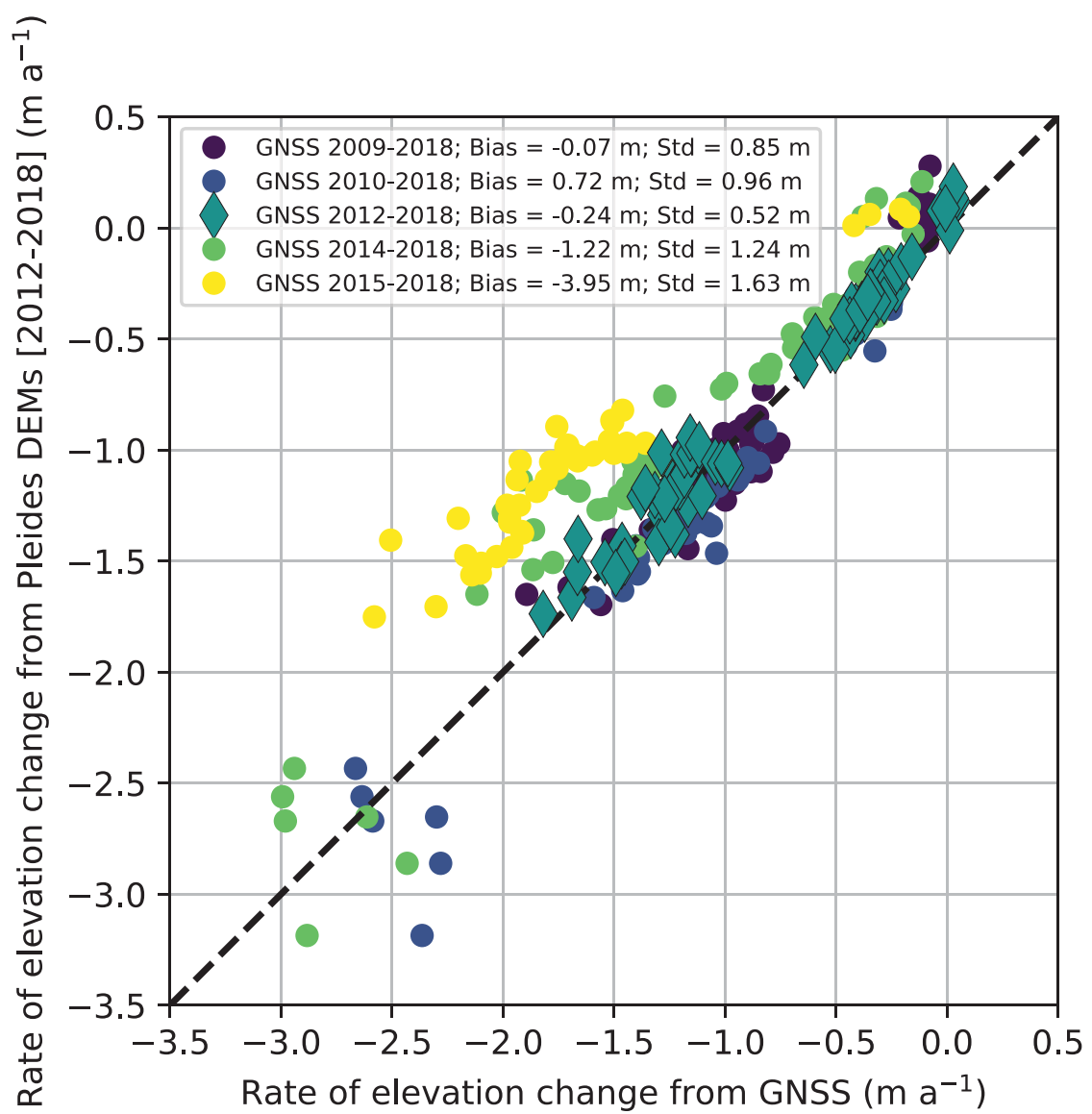

over snow and glaciers (e.g., Marti and others, 2016; Belart and others, 2017; Rieg and others, 2018).

\subsection{Calibration of the glaciological mass balance}

In case of a systematic bias in the glaciological mass balance, the standard and optimal procedure is to calibrate the glaciological mass balances with the geodetic results, in order to maintain the relative annual variability of the glaciological method while adjusting to the absolute multi-annual values of the geodetic method (e.g., Zemp and others, 2013). The glaciological mass balance, $B_{a}$, is calibrated by fitting it to the multi-annual geodetic mass balance, $B_{g}$, as follows:

$$
B_{a, c a l}=B_{a}+\left(B_{g}-\sum_{N} B_{a}\right) / N\left(\text { in m w.e. } \mathrm{a}^{-1}\right)
$$

where $B_{a, c a l}$ is the annual calibrated specific mass balance and $N$ is the number of years in the period during which the geodetic mass balance has been obtained. It is noteworthy to mention that the glaciological mass balance covers only the surface mass balance whereas the geodetic mass balance includes also the internal and basal balances, usually assumed small compared to the surface mass balance (Zemp and others, 2013).

\subsection{Detection of potential biases from the in situ measurement network}

To test potential sources of systematic error of the glaciological mass balance, we compare the mass balance obtained on the one hand with the glaciological profile method and on the other with the flux method (Reynaud and others, 1986). The surface-specific mass balance $B_{Z}$ of a certain zone of a glacier (referred with the subscript $Z$ ) can be described using the mass conservation equation (Cuffey and Paterson, 2010; Nuimura and others, 2011):

$$
B_{Z}=\rho\left[\frac{\delta h}{\delta t}-\frac{\left(\Phi_{i n, Z}-\Phi_{o u t, Z}\right)}{s_{Z}}\right]\left(\text { in mm w.e. } \mathrm{a}^{-1}\right)
$$

where $\rho$ is the ice density $\left(\mathrm{kg} \mathrm{m}^{-3}\right), h$ is the ice thickness $(\mathrm{m}), t$ is time (year), $\Phi_{i n, Z}$ (respectively $\Phi_{o u t, Z}$, in $\mathrm{m}^{3}$ of ice $\mathrm{a}^{-1}$ ) is the ice flux entering (respectively leaving) the zone of interest and $s_{Z}$ $\left(\mathrm{m}^{2}\right)$ is the area of interest.

We apply Eqn (6) to two areas of the glacier, the upper zone (subscript UZ) delineated by a $1246 \mathrm{~m}$ long cross section at $\sim 5520 \mathrm{~m}$ a.s.l. (referred as CS_5520) and the lower zone (subscript $L Z$ ) delineated by an $813 \mathrm{~m}$ long cross section at $\sim 5350 \mathrm{~m}$ a.s.l. (referred as CS_5350) (Fig. 3). Both zones are delineated manually according to the flow lines derived from the ITS_LIVE composite velocity field (Gardner and others, 2019) and the 2018 DEM lines, given that the upper zone contributes to the flow crossing CS_5520 and the lower zone is fed by the flow originating from CS_5350.

In the upper zone, $\Phi_{i n, U Z}=0$ so Eqn (6) gives $B_{U Z}=\rho[\delta h / \delta t+$ $\left.\left(\Phi_{\text {out }, U Z}\right) / s_{U Z}\right]$ and in the lower zone, $\Phi_{\text {out }, L Z}=0$ so $B_{L Z}=\rho[\delta h / \delta t-$ $\left(\Phi_{i n, L Z}\right) / s_{L Z}$ (Fig. 3). The thinning rates $\delta h / \delta t$ averaged over the upper and the lower zones are assessed through DEM differencing between 25 November 2012 and 28 October 2018 (5.93 years) and are $-0.05 \pm 0.07$ and $-1.42 \pm 0.11 \mathrm{~m} \mathrm{a}^{-1}$, respectively (Figs 1,4 ). We take an ice density of $850 \mathrm{~kg} \mathrm{~m}^{-3}$ (Huss, 2013) and $900 \mathrm{~kg}$ $\mathrm{m}^{-3}$ in the upper and lower zones, respectively. Ice fluxes through CS_5520 or CS_5350 ( $\Phi_{\text {out }, U Z}$ and $\Phi_{i n, L Z}$, respectively) are obtained by multiplying the cross-section area and the depth-averaged horizontal ice velocity of the corresponding area (see Wagnon and others, 2013 for details). Ground penetrating radar measurements performed in November 2009 provided an area of $61600 \pm 9200 \mathrm{~m}^{2}$ 


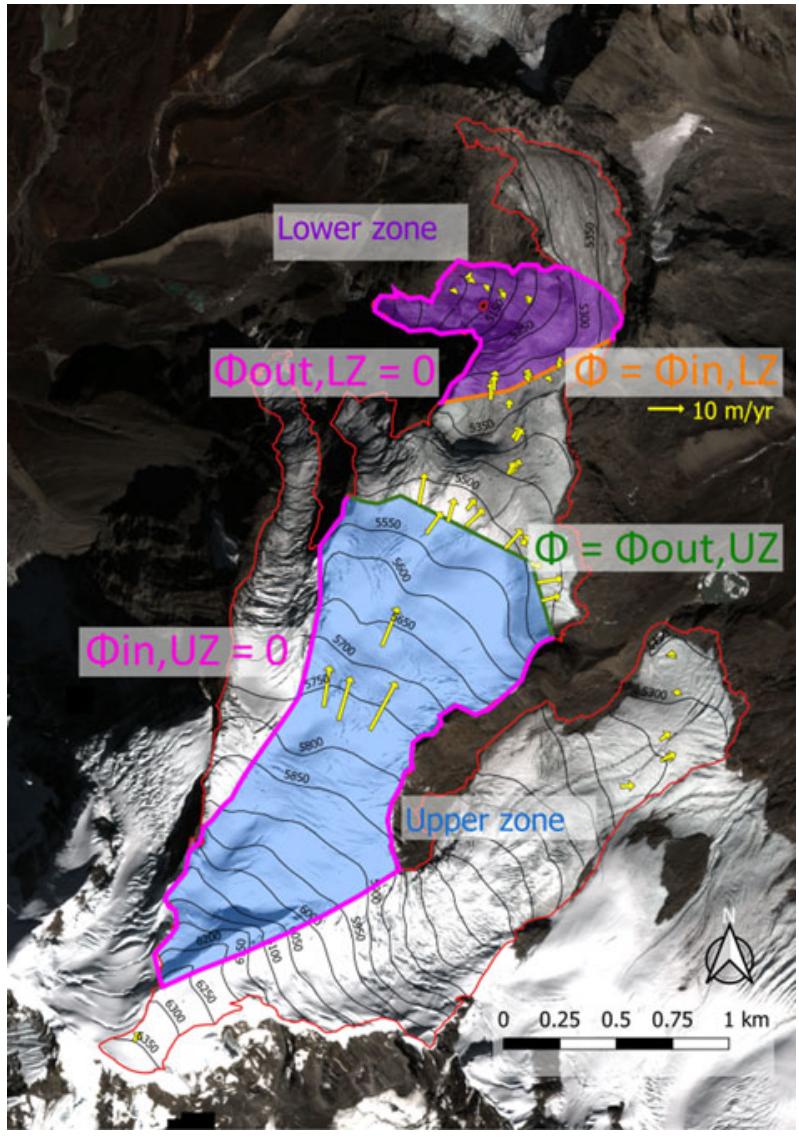

Fig. 3. Visualization of the upper zone (shaded blue area) contributing to the ice flux $\Phi_{\text {out }, u z}$ through the highest cross section at $\sim 5520 \mathrm{~m}$ a.s.l. (CS_5520, green thick line) and the lower zone (shaded purple area) fed by the ice flux $\Phi_{i n, L z}$ coming through the lowest cross section at $\sim 5350 \mathrm{~m}$ a.s.l. (CS 5350, orange thick line). Also shown are the field velocity measurements (yellow arrows) used to assess the ice flow through both cross sections. The background is a Pléiades ortho-image of 28 October 2018 (copyright CNES 2018, distribution Airbus D\&S). The 2012 glacier outline is shown in red.

(mean thickness of $49 \pm 7 \mathrm{~m}$ ) and $42400 \pm 6400 \mathrm{~m}^{2}$ (mean thickness of $52 \pm 8 \mathrm{~m}$ ) for CS_5520 and CS_5350, respectively (Wagnon and others, 2013). Based on the -0.62 and $-1.08 \mathrm{~m} \mathrm{a}^{-1}$ thinning rates calculated by DEM differencing between 2012 and 2018, along CS_5520 and CS_5350, respectively (Fig. 1 and Fig. 4), and taking into account that the thinning rates assessed by differential GNSS along both profiles between 2009 and 2018 are similar to those of
2012-18 (Fig. 2), we revise both section areas averaged over the period $2012-18$ to $56900 \pm 9200$ and $37100 \pm 6400 \mathrm{~m}^{2}$, respectively, corresponding to a mean thickness of $45 \pm 8 \mathrm{~m}$ for both sections. The depth-averaged horizontal ice velocity is derived from the mean surface ice velocity obtained by averaging the surface velocities available along each cross section and coming from the stake displacement measured by differential GNSS (Fig. 3). Based on our stake network, we do not detect surface velocity changes along CS_5520 or CS_5350 over the measurement period and velocities are considered unchanged compared with those of the period 2007-12 (Wagnon and others, 2013). Nye (1965) gives ratios of depth-averaged horizontal ice velocity to mean surface ice velocity varying from 0.8 (no sliding) to 1 (maximum sliding). Without information on the sliding of Mera Glacier, the depth-averaged horizontal ice velocity is assumed to be $(0.9 \pm 0.1) \times$ mean surface ice velocity along each cross section. The error range of the ice fluxes obtained with this method combines the error range for the cross-section areas and for the depth-averaged horizontal velocity. The ice fluxes at CS_5520 and CS_5350 are $0.35 \pm 0.10$ and $0.16 \pm 0.0510^{6} \mathrm{~m}^{3}$ of ice $\mathrm{a}^{-1}$.

\section{Results}

\subsection{Annual and cumulative glacier-wide glaciological mass balances between 2007 and 2019}

Table 1 gives the annual glacier-wide mass balances of Mera Glacier since 2007, as well as some classical glaciological variables such as glacier area, mass-balance gradients, equilibrium line altitude (ELA) and accumulation area ratio (AAR). Figure 5 displays the annual and cumulative mass balances of Mera Glacier assessed with the glaciological profile method between 2007 and 2019. Over this 12-year period, the mean glacier-wide mass balance $B_{a}$ is equal to $-0.30 \pm 0.28 \mathrm{~m}$ w.e. $\mathrm{a}^{-1}$, and almost similar over the period $2012-18$, with $B_{a}$ equal to $-0.31 \pm 0.28 \mathrm{~m}$ w.e. $\mathrm{a}^{-1}$.

\subsection{2-18 Geodetic mass balance}

Mera glacier area was $5.06 \pm 0.34 \mathrm{~km}^{2}$ in 2012 and $4.84 \pm 0.34 \mathrm{~km}^{2}$ in 2018. Higher thinning rates are observed in the lower part of the glacier. There is almost no thinning and area change above $5600 \mathrm{~m}$ a.s.l. (Fig. 1 and Fig. 4). The mean surface elevation change of Mera Glacier between 2012 and 2018 is $-3.00 \pm 0.27 \mathrm{~m}$, corresponding to cumulative and annual glacier-wide mass balances of $-2.55 \pm 0.34 \mathrm{~m}$ w.e. and $-0.42 \pm 0.06 \mathrm{~m}$ w.e. $\mathrm{a}^{-1}$, respectively.

Table 1. $B_{a}$, number of ablation (negative $b_{z}$ ) or accumulation measurements (positive $b_{z}$ ), total glacier area, equilibrium line altitude (ELA), accumulation area ratio (AAR) and mass-balance gradients $d b / d z$ for Mera Glacier

\begin{tabular}{|c|c|c|c|c|c|c|c|c|c|c|c|c|c|c|}
\hline Years & $07 / 08$ & $08 / 09$ & $09 / 10$ & $10 / 11$ & $11 / 12$ & $12 / 13$ & $13 / 14$ & $14 / 15$ & $15 / 16$ & $16 / 17$ & $17 / 18$ & $18 / 19$ & Mean & SD \\
\hline$B_{a}\left(\mathrm{~m}\right.$ w.e. $\left.\mathrm{a}^{-1}\right)$ & 0.27 & -0.24 & -0.64 & 0.37 & -0.79 & 0.30 & -0.30 & -0.11 & -0.31 & -0.65 & -0.81 & -0.69 & -0.30 & 0.43 \\
\hline Number of ablation measurements & 14 & 26 & 22 & 11 & 16 & 2 & 5 & 22 & 18 & 15 & 31 & 14 & 16 & \\
\hline Number of accumulation measurements & 7 & 5 & 4 & 11 & 1 & 5 & 4 & 5 & 5 & 4 & 2 & 3 & 5 & \\
\hline Total area $\left(\mathrm{km}^{2}\right)$ & 5.25 & 5.21 & 5.18 & 5.14 & 5.10 & 5.06 & 5.03 & 4.99 & 4.95 & 4.92 & 4.88 & 4.84 & 5.05 & 0.13 \\
\hline ELA (m a.s.l.) & 5427 & 5584 & 5680 & 5337 & 5802 & 5468 & 5557 & 5432 & 5585 & 5721 & 5769 & 5755 & 5593 & 154 \\
\hline AAR & 0.69 & 0.49 & 0.37 & 0.85 & 0.25 & 0.66 & 0.53 & 0.71 & 0.51 & 0.35 & 0.29 & 0.32 & 0.50 & 0.19 \\
\hline $\mathrm{db} / \mathrm{dz} \mathrm{z}_{\text {Mera }}\left(\mathrm{m}\right.$ w.e. $\left.(100 \mathrm{~m})^{-1} \mathrm{a}^{-1}\right)$ & 0.48 & 0.41 & 0.46 & 0.58 & 0.32 & $0.45^{\mathrm{a}}$ & $0.45^{\mathrm{a}}$ & 0.53 & 0.51 & 0.40 & 0.40 & 0.40 & 0.45 & 0.08 \\
\hline $\mathrm{db} / \mathrm{dz}$ Naulek $\left(\mathrm{m}\right.$ w.e. $\left.(100 \mathrm{~m})^{-1} \mathrm{a}^{-1}\right)$ & 0.97 & 0.74 & 0.97 & $0.87^{\mathrm{a}}$ & 0.72 & $0.87^{\mathrm{a}}$ & $0.87^{\mathrm{a}}$ & 0.95 & $0.87^{\mathrm{a}}$ & $0.87^{\mathrm{a}}$ & $0.87^{\mathrm{a}}$ & $0.87^{\mathrm{a}}$ & 0.87 & 0.13 \\
\hline $\mathrm{db} / \mathrm{dz}_{\text {Accu }}\left(\mathrm{m}\right.$ w.e. $\left.(100 \mathrm{~m})^{-1} \mathrm{a}^{-1}\right)$ & 0.03 & 0.04 & 0.07 & 0.05 & 0.15 & 0.04 & 0.09 & 0.12 & 0.08 & 0.04 & 0.07 & 0.11 & 0.08 & 0.04 \\
\hline$B_{\mathrm{a}, \mathrm{cal}}\left(\mathrm{m}\right.$ w.e. $\left.\mathrm{a}^{-1}\right)$ & 0.15 & -0.35 & -0.75 & 0.26 & -0.90 & 0.19 & -0.41 & -0.22 & -0.42 & -0.76 & -0.92 & -0.80 & -0.41 & 0.44 \\
\hline Error of $B_{\mathrm{a}, \text { cal }}\left(\mathrm{m}\right.$ w.e. $\left.\mathrm{a}^{-1}\right)$ & \pm 0.28 & \pm 0.26 & \pm 0.24 & \pm 0.22 & \pm 0.19 & \pm 0.16 & \pm 0.16 & \pm 0.16 & \pm 0.16 & \pm 0.16 & \pm 0.16 & \pm 0.19 & \pm 0.20 & \\
\hline $\mathrm{ELA}_{\text {cal }}$ (m a.s.l.) & 5450 & 5611 & 5704 & 5356 & 5836 & 5493 & 5582 & 5453 & 5607 & 5748 & 5796 & 5782 & 5618 & 157 \\
\hline $\mathrm{AAR}_{\mathrm{cal}}$ & 0.67 & 0.44 & 0.35 & 0.81 & 0.23 & 0.62 & 0.50 & 0.69 & 0.48 & 0.33 & 0.28 & 0.29 & 0.47 & 0.19 \\
\hline
\end{tabular}

Mass-balance gradients are distinguished between Mera, Naulek branches and the accumulation area (referred as Mera, Naulek and Accu subscripts, respectively) (Wagnon and others, 2013). The mean and standard deviation (SD) for each variable are also shown. Measurements are performed in November except early December in 2014 and 2015 . $B_{a, c a l}$, the annual glacier-wide mass balances calibrated with the 2012-18 geodetic mass balance are also shown, with their respective annual random errors (see section S3 in supplementary information for the calculation of this error), calibrated equilibrium line altitude (ELA $\left.A_{\text {cal }}\right)$ and calibrated accumulation area ratio $\left(\operatorname{AAR}_{\text {cal }}\right)$.

${ }^{a}$ Applying a 2007-19 mean gradient because not enough stakes were available to derive a linear fit. 


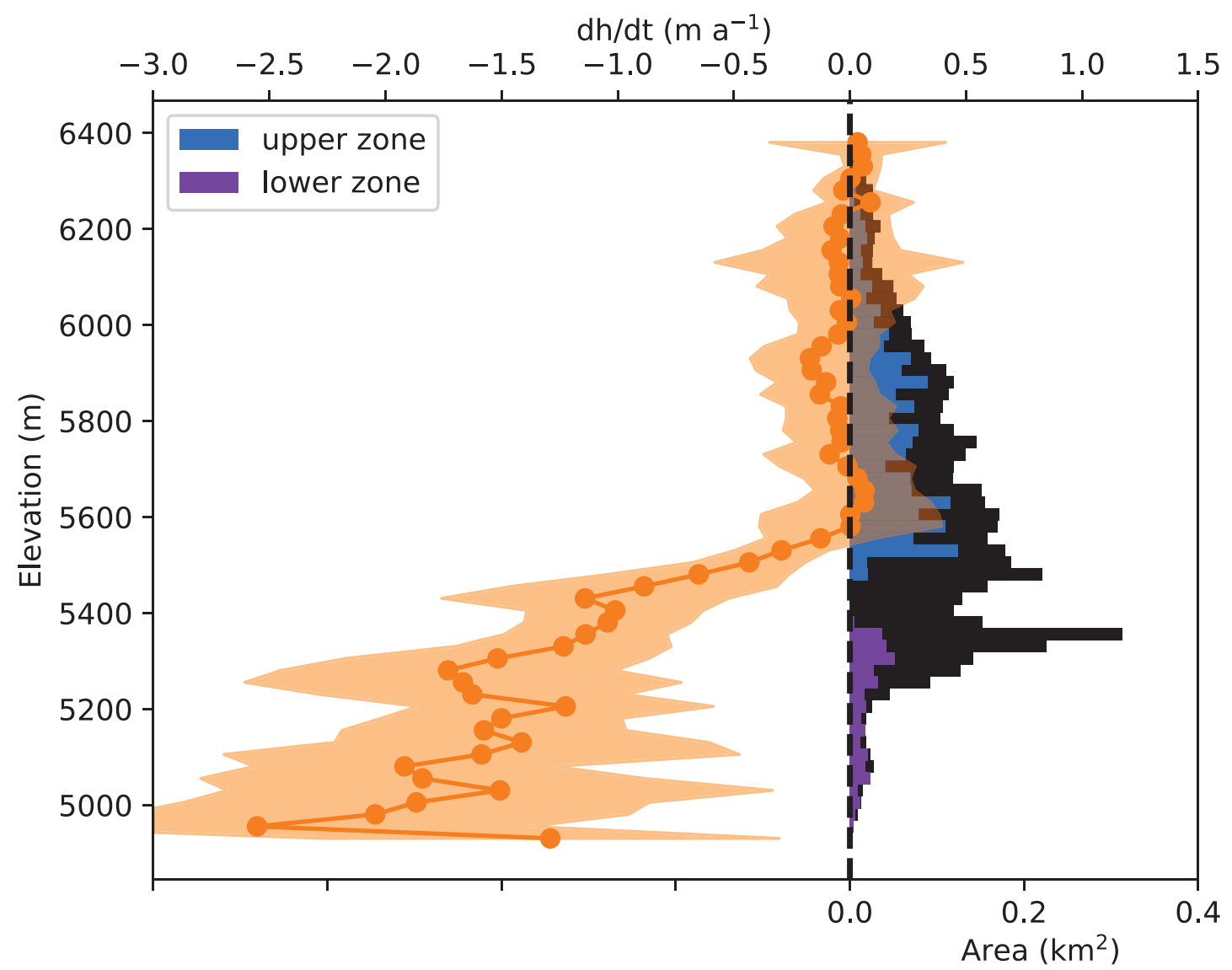

Fig. 4. 2012 hypsometry of the total glacier area (black histograms), including the upper zone (blue histograms) and the lower zone (purple histograms). The rate of elevation change as a function of elevation of Mera Glacier between 25 November 2012 and 28 October 2018 is shown by orange dots, and the orange shaded area corresponds to one standard deviation.

Fig. 5. Cumulative mass balance (MB) of Mera Glacier obtained with the glaciological profile method (black line with green dots) between November 2007 and November 2019, and calibrated (black line with blue dots) to match the 2012-18 geodetic mass balance (red triangles). The annual calibrated mass balances are shown as blue histograms.

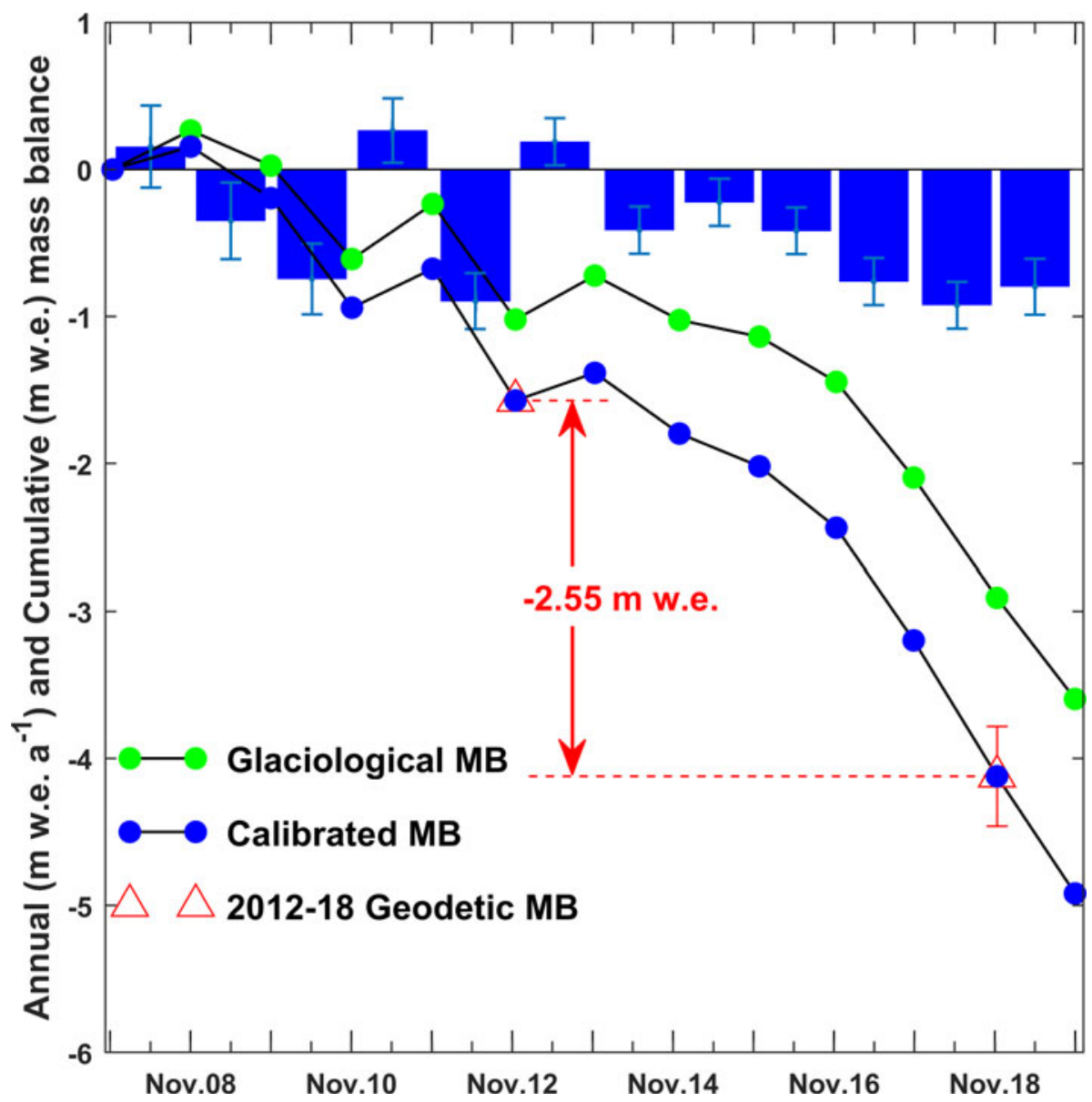




\subsection{Calibration of the glaciological mass balance}

Even though the error ranges overlap, the difference between the glaciological and the geodetic annual glacier-wide mass balance between 2012 and 2018 reaches $0.11 \mathrm{~m}$ w.e. $\mathrm{a}^{-1}$ suggesting that there is a systematic bias in the glaciological glacier-wide mass balance of Mera Glacier (Huss and others, 2015). Assuming that the bias is constant with time, and following Eqn (5), the annual glaciological mass balance is thus systematically decreased by $0.11 \mathrm{~m}$ w.e. $a^{-1}$ for each year of the measurement period from 2007 to 2019 , resulting in a cumulative mass balance of $-4.92 \mathrm{~m}$ w.e. and a mean calibrated glacier-wide mass balance $B_{a, c a l}$ of $-0.41 \pm$ $0.20 \mathrm{~m}$ w.e. $\mathrm{a}^{-1}$. This decrease of mass balance results in an upward shift of the ELA of $25 \mathrm{~m}$ with a mean ELA $_{\text {cal }}$ of $5618 \mathrm{~m}$ a.s.l. between 2007 and 2019 (Table 1). The random error, $\sigma_{B_{a, c a l}}$, of the calibrated annual glacier-wide mass balance over the period 2012-18 is calculated using Eqn (12) of Thibert and Vincent (2009). $\sigma_{B_{a, c a l}}$ is calculated as a quadratic sum of the error of the geodetic method i.e. $\sigma_{B_{g}}=0.34 \mathrm{~m}$ w.e. and the residuals of the nonlinear model of Vincent and others (2018) weighted over the total area of the glacier (see section S3 of supplementary information for the details of the calculations). Inside the 2012-18 calibration period, $\sigma_{B_{a, c a l}}$ is equal to $0.16 \mathrm{~m}$ w.e. $\mathrm{a}^{-1}$. Outside this period, $\sigma_{B_{a, c a l}}$ is larger than $0.16 \mathrm{~m}$ w.e. $\mathrm{a}^{-1}$ and is assumed to increase as a function of the time difference to the calibration period (Table 1 and section S3.2 of supplementary information).

The bias-corrected annual and cumulative mass balances are shown in Table 1 and Figure 5, together with the geodetic 2012-18 cumulative mass balance. Since 2013, we observe a succession of negative annual mass balances (mean $B_{a, c a l}=-0.59 \pm$ $0.17 \mathrm{~m}$ w.e. $\mathrm{a}^{-1}$ between 2013 and 2019), in agreement with the larger thinning rates observed along the profiles surveyed by differential GNSS between 2014 or 2015 and 2018 than those observed between 2009, 2010 or 2012 and 2018 (Fig. 2).

\subsection{Tracking the sources of bias}

Systematic errors may come from the natural spatial variability of point mass balance which is potentially not assessed properly due to insufficient field data or inaccurate spatial weighting relationship (Thibert and others, 2008). Comparing the mass balances of the upper and the lower zones of the glacier obtained by the glaciological method and the flux method (Fig. 3) allows to detect potential sources of biases. All data used to assess the specific mass balance of both zones are summarized in Table 2, together with their specific mass balance averaged over the period 201218, using the glaciological profile method described in Section 3.1.

Table 2. Specific annual mass balance $B_{Z}$ obtained over the period 2012-18 using the flux method and the glaciological method over two distinct zones of the glacier, the upper zone contributing to the ice flow through CS_5520 and the lower zone fed by the ice flow through CS_5350

\begin{tabular}{lcc}
\hline Period: $2012-18^{\mathrm{a}}$ & $\begin{array}{c}\text { Upper zone; } \\
\text { CS_5520 }\end{array}$ & $\begin{array}{c}\text { Lower zone; } \\
\text { CS_5350 }\end{array}$ \\
\hline Mean cross-section area $\left(\mathrm{m}^{2}\right)$ & $56900 \pm 9200$ & $37100 \pm 6400$ \\
Mean horizontal surface velocity $\left(\mathrm{m} \mathrm{a}^{-1}\right)$ & $6.9 \pm 0.2$ & $4.8 \pm 0.2$ \\
Depth averaged horizontal ice velocity $\left(\mathrm{m} \mathrm{a}^{-1}\right)$ & $6.2 \pm 0.7$ & $4.4 \pm 0.5$ \\
Ice flux $\left(10^{6} \mathrm{~m}^{3}\right.$ of ice $\left.\mathrm{a}^{-1}\right)$ & $0.35 \pm 0.10$ & $0.16 \pm 0.05$ \\
Total area $\left(\mathrm{km}^{2}\right)$ & $1.623 \pm 0.102$ & $0.368 \pm 0.053$ \\
Mean thinning rate $\left(\mathrm{m} \mathrm{a}^{-1}\right)$ & $-0.05 \pm 0.06$ & $-1.42 \pm 0.09$ \\
Volume change $\left(10^{6} \mathrm{~m}^{3}\right.$ of ice $\left.\mathrm{a}^{-1}\right)$ & $-0.08 \pm 0.10$ & $-0.52 \pm 0.08$ \\
$B_{Z}$ with flux method $\left(\mathrm{m}^{-1}\right.$ w.e. $\left.\mathrm{a}^{-1}\right)$ & $0.14 \pm 0.07$ & $-1.67 \pm 0.23$ \\
$B_{Z}$ with glaciological method $\left(\mathrm{m}\right.$ w.e. $\left.\mathrm{a}^{-1}\right)$ & 0.22 & -1.65
\end{tabular}

${ }^{a}$ All values below are calculated over the period 25 November 2012-28 October 2018, and converted into annual values dividing by 5.93 years.
In the lower zone, the mean annual specific mass balances over the period 2012-18 obtained by both methods are in very good agreement. Conversely, in the upper zone, the glaciological mass balance is more positive than the mass balance obtained by the flux method (Table 2). This over-estimation of the mass balance affects about one-third of the glacier i.e. most of the accumulation area.

\section{Discussion}

The mean annual specific mass balances over the period 2012-18, assessed on the one hand with the flux method and on the other with the glaciological method, are in good agreement in the lower zone of the glacier, but reveal an over-estimation of the mass balance obtained with the latter method in the upper zone (Table 2). This means that the measurement network installed on Mera Glacier is suitable to properly assess the mass balance in its ablation area, but tends to over-estimate the accumulation in the upper part. This is somehow expected as the number of measurement sites decreases with elevation, due to long and difficult access at high altitude. Moreover, snowdrift, sublimation and other wind-driven ablation processes are notoriously large at high elevation and likely responsible for an important spatial variability of mass balance (Wagnon and others, 2013; Litt and others, 2019), making the measurement network potentially poorly representative of the whole accumulation area. This large spatial variability of mass balance is driven by local topography and aspect variable over a few meters, as well as wind direction. However, the measurement network on Mera Glacier is not dense enough to capture this variability. As a consequence, the systematic over-estimation of the glaciological glacier-wide mass balance revealed by the comparison with the geodetic 2012-18 mass balance is likely mainly due to an over-estimation of accumulation by our limited measurement network in the upper part of the glacier. Nevertheless, the difference between the annual specific mass balance in the upper zone obtained by the flux method and the glaciological method (Table 2) is not large enough to explain completely this systematic over-estimation, suggesting that there are potentially other sources of bias not identified yet.

Our study corroborates the tendency for glaciological massbalance estimates world-wide to have a positive bias with roughly two-thirds of reanalyses producing more negative geodetic mass balances (e.g., Huss and others, 2009; Andreassen and others, 2016; Klug and others, 2018; O'Neel and others, 2019). The reasons for this bias remain often speculative and are mainly attributed to insufficient or erroneous accumulation measurements and a nonrepresentative spatial distribution of the point mass-balance measurements (Huss and others, 2009; Andreassen and others, 2016; Kapitsa and others, 2020). This bias is therefore expected to be smallest when the density and the spatial coverage of the measurement sites are highest and when the accumulation is lowest, such as for small to medium, easily accessible glaciers with limited turnover and during a period of considerable mass loss (Andreassen and others, 2016). For Mera Glacier, the origin of the bias is likely related to the spatial distribution of point massbalance measurements, especially in the accumulation zone where measurements are scarce.

Over the period 2007-19, the calibrated cumulative mass balance of Mera Glacier is equal to $-4.92 \mathrm{~m}$ w.e. (vs $-3.60 \mathrm{~m}$ w.e. before calibration) corresponding to a mean glacier-wide mass balance of $-0.41 \pm 0.20 \mathrm{~m}$ w.e. $\mathrm{a}^{-1}$. Even though the periods do not match, this calibrated mass balance seems in agreement with the region-wide mass balance of $-0.33 \pm 0.20 \mathrm{~m}$ w.e. $\mathrm{a}^{-1}$ between 2000 and 2016 (Brun and others, 2017) and $-0.36 \pm$ $0.09 \mathrm{~m}$ w.e. $\mathrm{a}^{-1}$ between 2000 and 2018 (Shean and others, 
2020) for the central Himalaya, suggesting that Mera Glacier is representative of this region. A comparison between Mera mass balance and region-wide mass balance over a common period is still required to confirm this fact.

Mera Glacier is thus far from being in balance and is losing more mass than originally assessed (Wagnon and others, 2013; Sherpa and others, 2017). Nevertheless and in agreement with Sherpa and others (2017), we still observe a contrasted pattern of surface mass balances of glaciers monitored in the Everest region, with mean 2010-19 glacier-wide mass balances of debris-free Mera, Pokalde $\left(0.09 \mathrm{~km}^{2}\right.$ in 2011 , elevation range $5330-5690 \mathrm{~m}$ a.s.l.) and West Changri Nup $\left(0.92 \mathrm{~km}^{2}\right.$ in 2013; elevation range 5430 $5690 \mathrm{~m}$ a.s.l.) glaciers of $-0.44 \pm 0.17 \mathrm{~m}$ w.e. $\mathrm{a}^{-1},-0.77 \pm 0.28 \mathrm{~m}$ w.e. $\mathrm{a}^{-1}$ and $-1.48 \pm 0.27 \mathrm{~m}$ w.e. $\mathrm{a}^{-1}$, respectively (see Table S2 in section S4 of supplementary information for annual mass balances of these three glaciers). In May 2016 in the nearby Rolwaling region, immediately west of the Everest region, Sunako and others (2019) started to monitor the debris-free Trambau Glacier $\left(23.34 \mathrm{~km}^{2}\right.$, elevation range 5060-6690 m a.s.l., $40 \mathrm{~km}$ from Mera Glacier) which is more than 4 times larger than Mera and located at similar elevations. They found a mean glacier-wide mass balance of $-0.61 \pm 0.39 \mathrm{~m}$ w.e. $\mathrm{a}^{-1}$ between May 2016 and October 2018, slightly less negative than the calibrated mass balance of Mera Glacier from April 2016 to November 2018 ( $-0.74 \pm 0.16 \mathrm{~m}$ w.e. $\left.\mathrm{a}^{-1}\right)$. Farther west, in the Langtang valley, the debris-free Yala Glacier $\left(1.37 \mathrm{~km}^{2}\right.$, elevation range $5143-5681 \mathrm{~m}$ a.s.l., $\sim 125 \mathrm{~km}$ from Mera Glacier) had a mean glacier-wide mass balance of $-0.81 \pm 0.27 \mathrm{~m}$ w.e. $\mathrm{a}^{-1}$ between November 2011 and November 2017 (Acharya and Kayastha, 2019), compared to $-0.42 \pm 0.17 \mathrm{~m}$ w.e. $\mathrm{a}^{-1}$ for Mera Glacier over the same period. Glaciers located at high elevations such as Mera or Trambau glaciers are losing mass less rapidly than those located at low elevations such as Yala, West Changri Nup and Pokalde glaciers, as already found at the scale of the High Mountain Asia (Brun and others, 2019). It seems also that since 2013, glaciers in the Everest region have been losing mass at an accelerated rate compared with the first part of the observation period, as revealed by glacier-wide mass balances (Table 1 and Fig. 4) and also by increased thinning rates since 2014 or 2015 (Fig. 2).

\section{Conclusion}

We use two DEMs derived from Pléiades stereo-images acquired on 25 November 2012 and 28 October 2018 to assess the geodetic mass balance of Mera Glacier. Thickness changes obtained by DEM differencing are validated in the field using differential GNSS surveys. The herewith validated geodetic mass balance is used as a reference to calibrate the glaciological mass balance which was on average too high by $0.11 \mathrm{~m}$ w.e. $\mathrm{a}^{-1}$ before calibration. The comparison between the specific mass balances assessed over two distinct zones of the glacier, delineated by cross sections whose thicknesses are known by GPR measurements, reveals that this over-estimation of the glacier-wide glaciological mass balance at least partly originates from an over-estimation of the mass balance in the accumulation area (Table 2). This is likely due to low spatial representativeness of the sparse measurement sites in this high-altitude area, prone to snowdrift and wind-driven ablation processes responsible for a large spatial variability of mass balance.

Between 2007 and 2019, Mera Glacier is in imbalance with a mean annual calibrated glacier-wide mass balance of $-0.41 \pm$ $0.20 \mathrm{~m}$ w.e. $\mathrm{a}^{-1}$, in general agreement with region-wide mass balances in the central Himalaya. Since 2013, we observe a succession of negative annual mass-balance years, with a mean annual 201319 glacier-wide mass balance of $-0.59 \pm 0.17 \mathrm{~m}$ w.e. $\mathrm{a}^{-1}$, although still less negative than that of glaciers located at lower altitude in the Everest region.
We are planning to maintain this monitoring programme on Mera Glacier in the coming years and hopefully over the long term, with repeated satellite image acquisitions to regularly validate and, if necessary, calibrate the glaciological mass balance, typically every 5-10 years. An effort will also be made to better assess accumulation at high elevation, with a focus on snow redistribution and wind-driven ablation processes. Multiplying measurement sites in the accumulation area is challenging but we are planning to combine different approaches (observation, remote sensing and modelling) to better assess local vertical gradients of precipitation and processes controlling the mass balance at high elevations such as accumulation, sublimation, or snowdrift.

Supplementary material. The supplementary material for this article can be found at https://doi.org/10.1017/jog.2020.88

Acknowledgements. This work has been supported by the French Service d'Observation GLACIOCLIM, now called CRYOBS-CLIM and part of IR OZCAR, the French National Research Agency (ANR) through ANR-13-SENV-0005-04/05-PRESHINE, and has been supported by a grant from Labex OSUG@2020 (Investissements d'avenir - ANR10 LABX56). This work would not have been possible without the support of the JEAI HIMALICE (PIs: D. Shrestha, and Y. Arnaud) and all the efforts from people in the field: porters, students, helpers who are greatly acknowledged here. This study was carried out within the framework of the Ev-K2-CNR Project in collaboration with the Nepal Academy of Science and Technology and Tribhuvan University. EB acknowledges support from the French Space Agency (CNES). Pléiades images were obtained thanks to the ISIS program at CNES. We are also grateful to Prof. Koji Fujita and two anonymous referees and the Scientific Editor Christoph Schneider, whose detailed comments and suggestions have significantly improved the original manuscript.

Data availability. All mass-balance data are available in the Glacioclim database at https://glacioclim.osug.fr/ and through the World Glacier Monitoring Service (WGMS) database.

Author contribution. PW and YA initiated the monitoring program on Mera, Pokalde and Changri Nup glaciers. PW and FB performed the analysis. $\mathrm{CV}$ and $\mathrm{PW}$ performed the error calculations. All authors participated in some field campaigns, contributed to the analysis and to the paper writing.

\section{References}

Acharya A and Kayastha RB (2019) Mass and energy balance estimation of Yala Glacier (2011-2017), Langtang Valley, Nepal. Water 11(6), 1-17. doi: $10.3390 /$ w11010006.

Andreassen LM, Elvehøy H, Kjøllmoen B and Engeset RV (2016) Reanalysis of long-term series of glaciological and geodetic mass balance for 10 Norwegian glaciers. The Cryosphere 10, 535-552. doi: $10.5194 / \mathrm{tc}-10$ $535-2016$

Azam FM and 10 others (2016) Meteorological conditions, seasonal and annual mass balances of Chhota Shigri Glacier, western Himalaya, India. Annals of Glaciology 71, 328-338. doi:10.3189/2016AoG71A570.

Azam FM and 5 others (2018) Review of the status and mass changes of Himalayan-Karakoram glaciers. Journal of Glaciology 64(243), 61-74. doi: 10.1017/jog.2017.86.

Belart JMC and 9 others (2017) Winter mass balance of Drangajökull ice cap (NW Iceland) derived from satellite sub-meter stereo images. The Cryosphere 11, 1501-1517. doi:10.5194/tc-11-1501-2017.

Berthier E and 10 others (2014) Glacier topography and elevation changes derived from Pléiades sub-meter stereo images. The Cryosphere 8, 22752291. doi:10.5194/tc-8-2275-2014.

Bolch T and 11 others (2019) Status and change of the cryosphere in the extended Hindu Kush Himalaya region. In Wester P, Mishra A, Mukherji A and Shrestha AB (eds), The Hindu Kush Himalaya Assessment: Mountains, Climate Change, Sustainability and People. Cham: Springer International Publishing, pp. 209-255. doi:10.1007/978-3-319-92288-1_7.

Brun F and 6 others (2019) Heterogeneous influence of glacier morphology on the mass balance variability in High Mountain Asia. Journal of Geophysical Research: Atmosphere 124(6), 1331-1345. doi: https://oi.org/ 10.1029/2018JF004838. 
Brun F, Berthier E, Wagnon P, Kääb A and Treichlert D (2017) A spatially resolved estimate of High Mountain Asia glacier mass balances, 2000-2016. Nature Geoscience 10(9), 668-673. doi: 10.1038/NGEO2999

Cuffey KM and Paterson WSB (2010) The Physics of Glaciers, 4th Edn. Amsterdam: Academic Press Inc.

Dolman AJ and 7 others (2016) A post-Paris look at climate observations. Nature Geoscience 9(9), 646-646.

Gardner AS, Fahnestock MA and Scambos TA (2019) ITS_LIVE regional glacier and ice sheet surface velocities. Data archived at National Snow and Ice Data Center. doi: 10.5067/6II6VW8LLWJ7

Höhle J and Höhle M (2009) Accuracy assessment of digital elevation models by means of robust statistical methods. \{ISPRS\} Journal of Photogrammetry and Remote Sensing 64(4), 398-406. doi: http://dx.doi.org/10.1016/j. isprsjprs.2009.02.003

Huss M (2013) Density assumptions for converting geodetic glacier volume change to mass change. The Cryosphere 7(3), 877-887. doi: 10.5194/ tc-7-877-2013

Huss M, Bauder A and Funk M (2009) Homogenization of long-term massbalance time series. Annals of Glaciology 50(50), 198-206. doi: 10.3189/ 172756409787769627

Huss M, Dhulst L and Bauder A (2015) New long-term mass-balance series for the Swiss Alps. Journal of Glaciology 61(227), 551-562. doi: 10.3189/ 2015JoG15J015

Immerzeel WW and 31 others (2019) Importance and vulnerability of the world's water towers. Nature 577(7790), 364-369. doi:10.1038/s41586019-1822-y.

Kapitsa V and 5 others (2020) Assessment of changes in mass balance of the Tuyuksu group of glaciers, northern Tien Shan between 1958 and 2016 using ground-based observations and Pleiades satellite imagery. Frontiers in Earth Science 8, 259-272. doi: 10.3389/feart.2020.00259.

Klug C and 8 others (2018) Geodetic reanalysis of annual glaciological mass balances (2001-2011) of Hintereisferner, Austria. The Cryosphere 12(3), 833-849. doi:10.5194/tc-12-833-2018.

Litt $\mathbf{M}$ and 6 others (2019) Glacier ablation and temperature indexed melt models in the Nepalese Himalaya. Scientific Reports 9(5264), 1-13. doi: 10.1038/s41598-019-41657-5.

Marti R and 5 others (2016) Mapping snow depth in open alpine terrain from stereo satellite imagery. The Cryosphere 10, 1361-1380. doi:10.5194/ tc-10-1361-2016.

McNabb R, Nuth C, Kääb A and Girod L (2019) Sensitivity of glacier volume change estimation to DEM void interpolation. The Cryosphere 13, 895-910. doi:10.5194/tc-13-895-2019.

Miles ES and 8 others (2018) Glacial and geomorphic effects of a supraglacial lake drainage and outburst event, Everest region, Nepal Himalaya. The Cryosphere 12(12), 3891-3905. doi:10.5194/tc-12-3891-2018.

Nuimura T and 5 others (2011) Temporal changes in elevation of the debriscovered ablation area of Khumbu Glacier in the Nepal Himalaya since 1978. Arctic, Antarctic, and Alpine Research 43(2), 246-255. doi: 10.1657/ 1938-4246-43.2.246.

Nuth C and Kääb A (2011) Co-registration and bias corrections of satellite elevation data sets for quantifying glacier thickness change. The Cryosphere 5(1), 271-290. doi: 10.5194/tc-5-271-2011

Nye JF (1965) The flow of a glacier in a channel of rectangular, elliptic or parabolic cross section. Journal of Glaciology 5(41), 661-690.
Oerlemans J (2001) Glaciers and Climate Change: A Meteorologist's View Lisse. The Netherlands: A.A. Balkema.

O'Neel S and 8 others (2019) Reanalysis of the US Geological Survey Benchmark Glaciers: long-term insight into climate forcing of glacier mass balance. Journal of Glaciology 65(253), 850-866. doi: 10.1017/jog. 2019.66

Pfeffer WT and 18 others (2014) The Randolph Glacier Inventory: a globally complete inventory of glaciers. Journal of Glaciology 60, 537-552. doi:10. 3189/2014JoG13J176.

Pritchard HD (2019) Asia's shrinking glaciers protect large populations from drought stress. Nature 569, 649-654. doi: 10.1038/s41586-019-1240-1

Reynaud L, Vallon M and Letreguilly A (1986) Mass-balance measurements: problems and two new methods of determining variations. Journal of Glaciology 32(112), 446-454.

Rieg L, Klug C, Nicholson L and Sailer R (2018) Pléiades Tri-Stereo Data for Glacier Investigations-Examples from the European Alps and the Khumbu Himal. Remote Sensing 10(10), 1563. doi: 10.3390/rs10101563

Shean DE and 6 others (2016) An automated, open-source pipeline for mass production of digital elevation models (DEMs) from very-high-resolution commercial stereo satellite imagery. \{ISPRS\} Journal of Photogrammetry and Remote Sensing 116, 101-117. doi:10.1016/j.isprsjprs.2016.03.012.

Shean DE and 5 others (2020) A systematic, regional assessment of high mountain Asia glacier mass balance. Frontiers in Earth Science 7, 363381. doi: $10.3389 /$ feart.2019.00363.

Sherpa SF and 8 others (2017) Contrasted surface mass balances of debris-free glaciers observed between the southern and the inner parts of the Everest region (2007-2015). Journal of Glaciology 63(240), 637-651. doi: 10.1017/ jog.2017.30.

Sunako S, Fujita K, Sakai A and Kayastha RB (2019) Mass balance of Trambau Glacier, Rolwaling region, Nepal Himalaya: in-situ observations, long-term reconstruction and mass balance sensitivity. Journal of Glaciology 65(252), 605-616. doi: 10.1017/jog.2019.37

Thibert E, Blanc R, Vincent C and Eckert N (2008) Glaciological and volumetric mass-balance measurements: error analysis over 51 years for Glacier de Sarennes, French Alps. Journal of Glaciology 54(186), 522-532. doi: 10. 3189/002214308785837093

Thibert E and Vincent C (2009) Best possible estimation of mass balance combining glaciological and geodetic methods. Annals of Glaciology $\mathbf{5 0}$ (50), 112-118. doi: 10.3189/172756409787769546

Vincent C and 10 others (2016) Reduced melt on debris-covered glaciers: investigations from Changri Nup Glacier, Nepal. The Cryosphere 10, 1845-1858. doi:10.5194/tc-10-1845-2016.

Vincent C and 14 others (2018) A nonlinear statistical model for extracting a climate signal from glacier mass balance measurements. Journal of Geophysical Research - Earth Surface 123, 2228-2242. doi:10.1029/ 2018JF004702.

Wagnon P and 11 others (2013) Seasonal and annual mass balances of Mera and Pokalde glaciers (Nepal Himalaya) since 2007. The Cryosphere 7, 1769-1786. doi:10.5194/tc-7-1769-2013.

Zemp M and 16 others (2013) Reanalysing glacier mass balance measurement series. The Cryosphere 7, 1227-1245. doi: 10.5194/ tc-7-1227-2013.

Zemp M and 14 others (2019) Global glacier mass changes and their contributions to sea level rise from 1961 to 2016. Nature 568, 382-386. doi:10. 1038/s41586-019-1071-0. 